\title{
PENENTUAN UNSUR TANAH JARANG KELOMPOK SEDANG SECARA VOLTAMMETRI PINDAI LINIER MENGGUNAKAN ELEKTRODE GRAFIT PENSIL
}

\author{
Yeni Wahyuni Hartati ${ }^{*}$, Elsa Nur Utami, Diana Hendrati, Titin Sofyatin \\ Departemen Kimia FMIPA Universitas Padjadjaran \\ Email: yeni.w.hartati@unpad.ac.id
}

\begin{abstract}
Rare earth elements play an important role in a variety of applications, mostly for high-tech industries. But their presence in mineral jointly separation makes it difficult to determine the content of rare earths because each element has physical and chemical properties are almost identical. The purpose of this study is the use of a linear scan voltammetry method to study the electrochemical characteristics of the medium rare earth element group (Sm, $G d, E u, T b)$, as an alternative method of separation and analysis of rare earth elements. The electrode used is a graphite pencil electrodes without modification, with a variety of supporting electrolyte. The results obtained show some supporting electrolyte provides good reduction peak for gadolinium, compared to the peaks of the reduction potential of the single rare earth ions other. The potential range of the most well using pencil graphite electrode obtained at $0.50 \mathrm{~V}$ to $-1.00 \mathrm{~V}$. Analysis of single gadolinium provide linear regression equation in a concentration range of 4.0 to $10.0 \mathrm{mg} / \mathrm{L}$ by the equation $Y=0.9862 X+$ 0.828 with $R 2=0.9954$. The limit of detection is determined from the linear regression obtained $0.72 \mathrm{mg} / \mathrm{L}$.
\end{abstract}

Keywords: Rare earth elements, Gadolinium, Voltammetry, Medium rare earth group.

\section{PENDAHULUAN}

Unsur tanah jarang merupakan material yang strategis, sukar diperoleh, dan mempunyai kegunaan yang luas. Pemakaian unsur tanah jarang baik secara individual maupun dalam bentuk campurannya, saat ini menunjukkan kecenderungan yang terus meningkat [1,2]. Hal ini disebabkan karena unsur tanah jarang memiliki kekuatan mekanis yang cukup baik, titik leleh yang relatif tinggi dan mempunyai tampang lintang serapan neutron yang besar sehingga banyak dimanfaatkan dalam bidang teknologi. Unsur tanah jarang memberikan perkembangan teknologi yang cukup signifikan dalam ilmu material. Pengelompokan unsur tanah jarang secara konvensial unsur tanah jarang dibagi menjadi tiga kelompok [3] yaitu unsur tanah jarang berat, sedang, dan ringan. Pengelompokkan berdasarkan nomor atom dan berat massa atom [4]. Kelompok sedang yaitu samarium, europium, gadolinium, dan terbium. 
Pengolahan atau pemisahan unsur tanah jarang untuk mendapatkan kandungan dalam mineralnya tidaklah mudah. Letak kesulitan dalam memperoleh logam tanah jarang murni adalah sulitnya memisahkan antara unsur lantanida yang satu dengan unsur yang lainnya, akibat dari sifatnya yang mirip, sehingga cara kimia biasa sangat sulit dilakukan. Analisis unsur-unsur tanah jarang pada umumnya dilakukan dengan metode graphite furnace atomic absorption spectrometry (GF-AAS) [5], spektrometri [6], inductively coupled plasma-atomic emission spectrometry (ICP-AES) [7], inductively coupled plasma-mass spectrometry [8-10], dan electrode ion selektif $[11,12]$. Pengembangan metode masih terus dilakukan untuk pengoperasian lebih mudah dan biaya lebih rendah, namun sensitivitasnya tinggi.

Metode voltammetri mempunyai keunggulan diantaranya dalam penyediaan cuplikan yang sederhana dan waktu analisis yang cepat. Penyediaan cuplikan yang diperlukan biasanya hanya pelarutan tanpa pemekatan dan pemisahan unsur-unsur mayornya, sehingga mengurangi sumber kesalahan dengan batas deteksi sampai $0,1 \mu \mathrm{g} / \mathrm{L}$ [13]. Kinerja dari metode voltammetri sangat dipengaruhi oleh material elektode kerja. Elektrode merkuri telah terbukti sangat baik untul analisis $[14,15]$. Namun karena toksisitas dari merkuri, maka dikembangkan electrode lain yang lebih ramah lingkungan.

Pada penelitian ini dipelajari mengenai karakteristik elektrokimia dari beberapa ion tanah jarang kelompok sedang yaitu gadolinium, samarium, europium, dan terbium. Teknik elektroanalisis yang digunakan adalah secara voltammetri menggunakan elektrode kerja grafit pensil dengan elektrode pembanding $\mathrm{Ag} / \mathrm{AgCl}(\mathrm{KCl} 3 \mathrm{M})$ dan elektrode pembantu Pt.

Hasil dari penelitian diharapkan dapat memberikan kontribusi ilmiah dalam metode elektroanalisis, dapat diaplikasikan dalam pemisahan mineral secara langsung agar mineral memiliki nilai jual yang tinggi.

\section{METODE PENELITIAN}

Alat

Peralatan yang digunakan dalam penelitian ini adalah potensiostat Metrohm ${ }^{\circledR} \mu$ Autolab yang terhubung ke komputer menggunakan software NOVA 7.0.0. Sel voltammetri $14 \mathrm{~mL}$, elektrode grafit pensil (Faber Castlee) dengan diameter 0,5 mm sebagai elektrode kerja, platina sebagai elektrode pembantu dan elektrode $\mathrm{Ag} / \mathrm{AgCl}\left(\right.$ Metrohm $\left.{ }^{\circledR}\right)$ sebagai elektrode pembanding, magnetic strirrer, spatula, pipet mikro (Ependorf), tip pipet, kertas parafilm, dan alat-alat gelas.

\section{Bahan}

Bahan penelitian yang digunakan dalam penelitian ini adalah akuabides (Ikapharmindo), asam klorida (Merck) 0,1 M, asam nitrat (Merck) 0,1 M, kalium klorida (Merck) 0,1 M, natrium klorida (Merck) 0,1 M, ammonium klorida (Merck) 0,1 M, samarium oksida, europium oksida, gadolinium oksida, dan terbium oksida (Sigma).

\section{Prosedur Kerja}


Semua prosedur pembuatan dan pengenceran larutan dilakukan berdasarkan metode baku. Larutan elektrolit pendukung (akuades, asam nitrat $0,1 \mathrm{M}$, asam klorida $0,1 \mathrm{M}$, kalium klorida $0,1 \mathrm{M}$, natrium klorida $0,1 \mathrm{M}$ dan buffer asetat $0,1 \mathrm{M}$ ), dan $10 \mathrm{mg} / \mathrm{mL}$ larutan ion tanah jarang tunggal diukur secara linier sweep voltammetry. Kondisi kerja diatur pada pembacaan rentang potensial $0,00 \mathrm{~V}$ sampai $-2,00 \mathrm{~V}$ vs $\mathrm{Ag} / \mathrm{AgCl}$. Prosedur ini dilakukan pada elektrode kerja grafit pensil. Untuk penentuan batas deteksi pengukuran, dibuat variasi konsentrasi 1,0 $100,0 \mathrm{mg} / \mathrm{mL}$ gadolinium dan diukur menggunakan elektrolit pendukung ammonium klorida 0,1 M.

\section{HASIL DAN PEMBAHASAN}

Pengujian pemilihan elektrolit pendukung ini meliputi akuabides, asam klorida $0,1 \mathrm{M}$, asam nitrat $0,1 \mathrm{M}$, kalium klorida $0,1 \mathrm{M}$, ammonium klorida $0,1 \mathrm{M}$, dan buffer asetat $0,1 \mathrm{M}$. Dari hasil pengukuran dari beberapa elektrolit pendukung tersebut, puncak potensial reduksi dalam voltammogram unsur-unsur tanah jarang ini sangat berdekatan. Contoh di bawah ini adalah voltammogram dalam akuabides dan ammonium klorida $0,1 \mathrm{M}$.

Voltammogram secara pindai linier dilakukan pada rentang potensial daerah elektrode yang terpolarisasi, $0,50 \mathrm{~V}$ s.d $-1,00 \mathrm{~V}$ dan $0,00 \mathrm{~V}$ s.d $-2,00 \mathrm{~V}$. Gambar 1 menunjukkan voltammogram ion-ion tanah jarang kelompok sedang tunggal dalam larutan pendukung akuabides, pada rentang $0,50 \mathrm{~V}$ sampai $-1,00 \mathrm{~V}$. Pengukuran masing-masing ion tanah jarang tunggal menghasilkan arus puncak tunggal untuk samarium, europium, dan gadolinium terdeteksi pada potensial reduksi sekitar $-0,55 \mathrm{~V}$ hingga $0,70 \mathrm{~V}$, sedangkan terbidium tidak memberikan puncak reduksi pada rentang ini. Perbandingan dengan pindai rentang $0,00 \mathrm{~V}$ hingga $-2,00 \mathrm{~V}$ ditunjukkan pada Tabel 1 . Dengan rentang pindai yang lebih lebar, terbium menunjukkan puncak pada daerah sekitar $-1,50 \mathrm{~V}$, sedangkan tiga unsur lainnya menunjukkan adanya dua puncak reduksi.

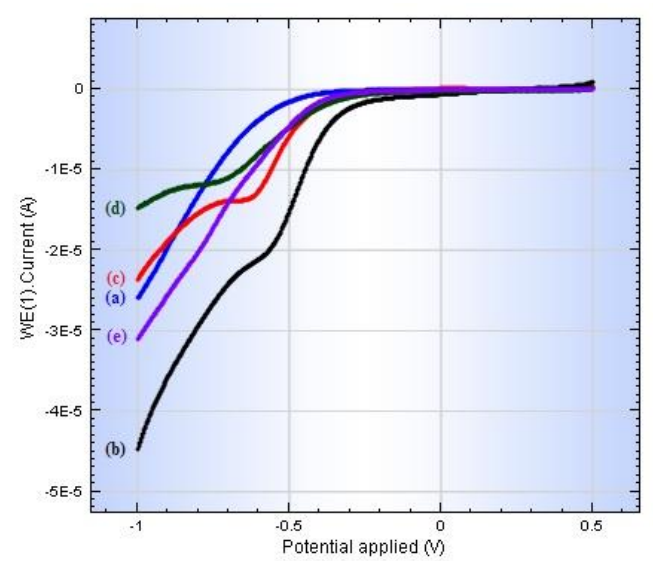

Gambar 1. (a) Akuabides; (b) Samarium; (c) Europium; (d) Gadolinium; (e) Terbium. Kondisi: laju pindai $50 \mathrm{mv} /$ detik, konsentrasi masing-masing $\quad 10 \mathrm{mg} / \mathrm{L}$. 
Tabel 1. Potensial Reduksi Unsur Tanah Jarang Sedang Menggunakan Akuabides

\begin{tabular}{ccc}
\hline Unsur & \multicolumn{2}{c}{ Potensial reduksi (V) vs Ag/AgCl } \\
\cline { 2 - 3 } Tanah & $\mathbf{0 , 5 0}$ s.d $\mathbf{- 1 , 0 0}$ & $\mathbf{0 , 0 0}$ s.d $-\mathbf{2 , 0 0}$ \\
Jarang & $-0,55$ & $-0,75$ dan $-1,10$ \\
\hline Samarium & $-0,60$ & $-0,70$ dan $-1,40$ \\
Europium & $-0,70$ & $-0,70$ dan $-1,30$ \\
Gadolinium & - & $-1,50$ \\
Terbium & & \\
\hline
\end{tabular}

Hasil pengukuran unsur tanah jarang $10 \mathrm{ppm}$ dalam $\mathrm{NH} 4 \mathrm{Cl} 0,1 \mathrm{M}$ dalam rentang potensial $0,50 \mathrm{~V}$ s.d $-1,00 \mathrm{~V}$ ditunjukkan pada Gambar 2. Voltammogram terdeteksi adanya arus puncak pada unsur tanah jarang samarium, europium, gadolinium, dan terbium yaitu pada potensial reduksi berdekatan, sekitar $-0,60 \mathrm{~V}--0,70 \mathrm{~V}$. Sedangkan pada rentang potensial $0,00 \mathrm{~V}$ s.d $-2,00 \mathrm{~V}$ perbandingannya ditunjukkan pada Tabel 2.

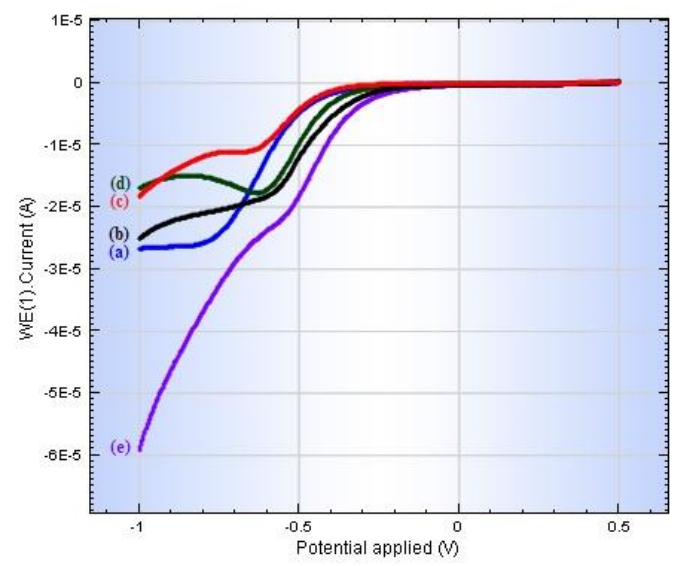

Gambar 2. (a) Amonium klorida 0,1 M ; (b) Samarium; (c) Europium; (d) Gadolinium; (e) Terbium. Kondisi: laju pindai $50 \mathrm{mv} / \mathrm{detik}$, konsentrasi masing-masing $10 \mathrm{mg} / \mathrm{L}$. 
Tabel 2. Potensial Reduksi Unsur Tanah Jarang Sedang Menggunakan $\mathrm{NH}_{4} \mathrm{Cl}$

\begin{tabular}{ccc}
\hline Unsur & \multicolumn{2}{c}{ Potensial reduksi $(\mathbf{V})$ vs Ag/AgCl } \\
\cline { 2 - 3 } Tanah & $\mathbf{0 , 5 0}$ s.d $\mathbf{- 1 , 0 0}$ & $\mathbf{0 , 0 0}$ s.d $\mathbf{- 2 , 0 0}$ \\
Jarang & $-0,60$ & $-0,60$ dan $-1,15$ \\
\hline Samarium & $-0,65$ & $-0,65$ \\
Europium & $-0,65$ & $-0,65$ \\
Gadolinium & $-0,55$ & $-0,55$ dan $-1,30$ \\
Terbium & \\
\hline
\end{tabular}

Dengan menggunakan larutan pendukung buffer asetat $\mathrm{pH} 5,0,0,1 \mathrm{M}$ pada rentang 0,50 s.d $-2,00 \mathrm{~V}$, puncak reduksi samarium pada daerah $-0,60 \mathrm{~V}$, terbidium pada $-0,65 \mathrm{~V}$, dan europium $-1,20 \mathrm{~V}$, sedangkan gadolinium tidak menunjukkan puncak. Tabel 3 menunjukkan data puncak reduksi untuk ion-ion tanah jarang tunggal dalam berbagai elektrolit pendukung.

Tabel 3. Potensial Reduksi Unsur Tanah Jarang Sedang Menggunakan Berbagai Elektrolit Pendukung

\begin{tabular}{|c|c|c|c|c|}
\hline \multirow{2}{*}{$\begin{array}{l}\text { Elektrolit } \\
\text { pendukung }\end{array}$} & \multicolumn{4}{|c|}{ Potensial reduksi (V) vs Ag/AgCl } \\
\hline & Samarium & Europium & Gadolinium & Terbium \\
\hline Akuabides & $\begin{array}{c}-0,75 \text { dan }- \\
1,10\end{array}$ & $\begin{array}{c}-0,70 \text { dan }- \\
1,40\end{array}$ & $-0,70$ dan $-1,30$ & $-1,50$ \\
\hline $\begin{array}{l}\text { Asam klorida } \\
0,1 \mathrm{M}\end{array}$ & - & - & $-0,50$ & - \\
\hline $\begin{array}{l}\text { Asam nitrat } \\
0,1 \mathrm{M}\end{array}$ & - & - & $-0,50$ & - \\
\hline $\begin{array}{l}\text { Kalium } \\
\text { klorida } 0,1 \\
\text { M,. }\end{array}$ & $-0,40$ & - & $-0,40$ & - \\
\hline $\begin{array}{l}\text { Ammonium } \\
\text { klorida } 0,1 \\
\text { M, }\end{array}$ & $\begin{array}{c}-0,60 \text { dan - } \\
1,15\end{array}$ & $-0,65$ & $-0,65$ & $\begin{array}{c}-0,55 \text { dan } \\
-1,30\end{array}$ \\
\hline $\begin{array}{l}\text { Buffer asetat } \\
\text { pH 5,0, 0,1 } \\
\text { M. }\end{array}$ & $-0,65$ & $-1,20$ & - & $-0,65$ \\
\hline
\end{tabular}

Pengukuran gadolinium tunggal dilakukan dengan variasi konsensentrasi 4,0 - 10,0 $\mathrm{mg} / \mathrm{mL}$ dan diukur sebanyak tiga kali pada masing-masing konsentrasi. Pengukuran dilakukan 
dengan menggunakan EGP pada rentang potensial 1,00 V sampai -1,00 V secara pindai linier. Voltamogram variasi konsentrasi gadolinium ditunjukkan pada Gambar 3.

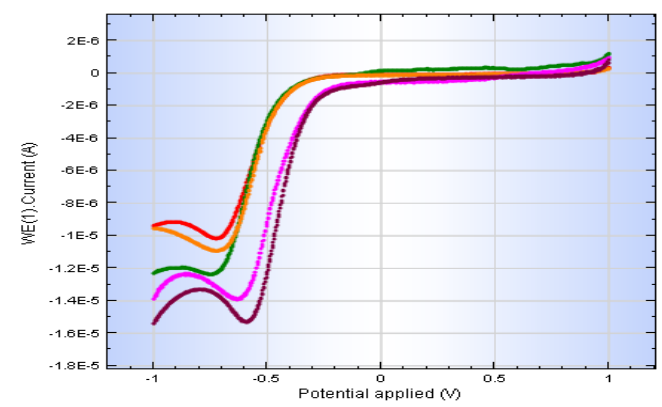

Gambar 3. Voltammogram Pindai Linier Gadolinium Pada Variasi Konsentrasi 1,00 V Sampai $1,00 \mathrm{~V}$ Vs Ag/Agcl

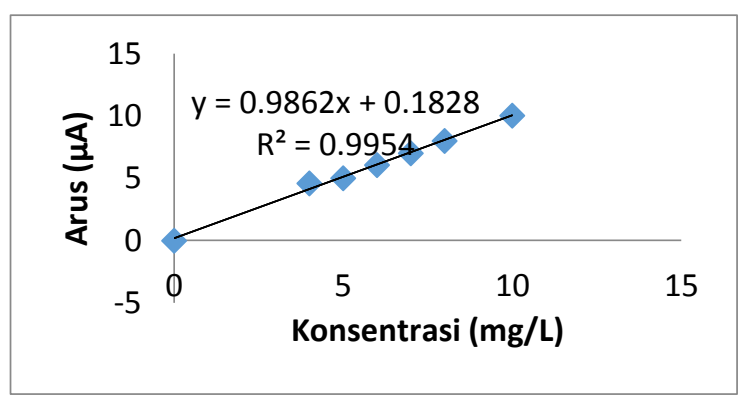

Gambar 4. Kurva Kalibrasi Variasi Konsentrasi Gadolinium 0,0 - 10,0 Mg/L Dalam Ammonium Klorida 0,1 M.

Dari Gambar 4 ditunjukkan bahwa terdapat hubungan linier antara konsentrasi gadolinium dengan tinggi arus puncak, dengan persamaan kurva kalibrasi $\mathrm{Y}=0,9862 \mathrm{X}+0,828$ dengan nilai R2=0,9954. Batas deteksi ditentukan dari regresi linier diperoleh 0,72 mg/L.

\section{PENUTUP}

\section{Kesimpulan}

Berdasarkan penelitian yang telah dilakukan, diperoleh kesimpulan bahwa dalam beberapa elektrolit pendukung, unsur-unsur tanah jarang sedang menunjukkan potensial reduksi yang berdekatan, sehingga akan sulit untuk dipisahkan berdasarkan perbedaan nilai potensial reduksi. Gadolinium dapat dipisahkan atau dianalisis dalam elektrolit pendukung asam klorida 0,1 M dan asam nitrat 0,1 M, karena unsur-unsur kelompok tanah jarang sedang yang lainnya tidak memberikan respon pada daerah potensial sekitar $-0,60 \mathrm{~V}$ vs $\mathrm{Ag} / \mathrm{AgCl}$. Untuk analisis kandungan masing-masing unsur tanah jarang kelompok sedang ini secara voltammetri dapat dilakukan terhadap campurannya dengan metode multivariat.

\section{Ucapan terima kasih}


Terima kasih kepada Prof. Dr. Husein H. Bahti dan Dr. Muthalib, untuk diskusi dan saransaran selama melakukan penelitian.

\section{DAFTAR PUSTAKA}

B. Zhu, D. Wu, Y, Yang, Y. Chen, W. Li, J. Guo, Q. Wang, Selective Removal of La(III) Ions Using Super-Paramagnetic Nanosorbent Coated by Saponified sec-Octylphenoxy Acetic Acid. J. Chem. Eng. Data., 57 (2012) 553.

D. Wu, L. Zhang, L. Wang, B. Zhu, L. Fa, Adsorption of lanthanum by magnetic alginatechitosan gel beads, J. Chem. Technol. Biotechnol., 86 (2011) 345.

Fontana, D \& Loris, F. 2009. Separation of Middle Rare Earths by Solvent Extraction Using 2ethylheksylphosphonic acid mono-2-ethylheksyl ester. Journal of Rare Earth. 27: 830-833.

Suwargi, E., B. Pardiarto \& T. Ishlah. 2010. Potensi Logam Tanah Jarang di Indonesia. Buletin Sumber Daya Geologi. 5 (3), 131-140.

A. Skroce, M. McCormick, B. Meehan, V. Dolic, K. Peverill, Determination of lanthanum by graphite furnace atomic absorption spectrometry with a tantalum platform. Spectrochim. Acta, Part B, 48 (1993) 1639.

V.K. Jain, A. Handa, S.S. Sait, P. Shrivastav, Y.K. Agrawal, Pre-concentration, separation and trace determination of lanthanum(III), cerium(III), thorium(IV) and uranium(VI) on polymer supported o-vanillinsemicarbazone, Anal. Chim. Acta, 429 (2001) 237.

Y.K. Agrawal, P. Shrivastav, Solvent extraction, spectrophotometric and inductively coupled plasma atomic emission spectroscopic (ICP-AES) determination of lanthanum(III) with crown hydroxamic acid. Talanta, 44 (1997) 1307.

Fujimori E., Hayashi T., Inagaki K., Haraguchi H. Determination of lanthanum and rare earth elements in bovine whole blood reference material by ICP-MS after coprecipitation preconcentration with heme-iron as coprecipitant. Fresenius' J. Anal. Chem. 1999;363:277282.

F.A. Aydin, M. Soylak, Separation, preconcentration and inductively coupled plasma-mass spectrometric (ICP-MS) determination of thorium(IV), titanium(IV), iron(III), lead(II) and chromium(III) on 2-nitroso-1-naphthol impregnated MCI GEL CHP20P resin. J. Hazard. Mater., 173 (2010) 669.

Khalil, Sabry. "Ion-selective electrode for lanthanum determination in standard samples." Analytical letters 36.7 (2003): 1335-1349.

M.R. Ganjali, V. Akbar, M. Ghorbani, P. Norouzi, A. Ahmadi, Fluoride determination in some mouth wash preparations by a novel La (III) graphite coated membrane sensor based on amitraz. Anal. Chim. Acta, 531 (2005) 185.

M. Akhond, M.B. Najafi, J. Taskhourian, Lanthanum-selective membrane electrode based on 2, 2'-dithiodipyridine. Anal. Chim. Acta, 531 (2005) 179.

Wang, J. 2000. Analytical Electrochemistry. Wiley-VCH. New York. 
M. Javanbakht, H. Khoshsafar, M.R. Ganjali, P. Norouzi, M. Adib, Adsorptive Stripping Voltammetric Determination of Nanomolar Concentration of Cerium (III) at a Carbon Paste Electrode Modified by N'-[(2-Hydroxyphenyl). Electroanalysis, 21 (2009) 1605.

B. Sebez, B. Ogorevc, S.B. Hocevar, M. Veber, Functioning of antimony film electrode in acid media under cyclic and anodic stripping voltammetry conditions. Anal. Chim. Acta, 785 (2013) 43. 